\title{
Feasibility Assessment of Hydroelectric Power Plant in Ungauged River Basin: A Case Study
}

\author{
M. Cihat Tuna
}

Received: 11 May 2011 / Accepted: 18 August 2011 / Published online: 21 February 2013

(C) The Author(s) 2013. This article is published with open access at Springerlink.com

\begin{abstract}
The accurate estimation of long-term resource availability, as represented by discharge, is an essential component of hydropower constructions for generation capacity estimation as well as environment protection on ungauged river basins. Feasibility studies concerning decision-making for various types of items to be used in a hydropower plant on ungauged river basins are important in order to estimate the energy generation, the approximate cost of the project, and the required budget allocation. A feasibility study is necessary which evaluates the energy generation cost, investment and maintenance costs for hydropower projects. The purpose of this study is to analyze the technical feasibility of hydropower plant installations at ungauged sites. A case study is performed to illustrate this investigation. By means of the methodology presented in this research work, it will be possible to carry out sound and successful research to assess the economic feasibility of a hydropower project on ungauged river basins.
\end{abstract}

Keywords Hydropower - Feasibility report .

Ungauged river basin $\cdot$ Cost estimation .

Income-expense ratio

M. C. Tuna ( $\varangle)$

Civil Engineering Department, Firat University,

23119 Elazig, Turkey

e-mail: mctuna@ firat.edu.tr

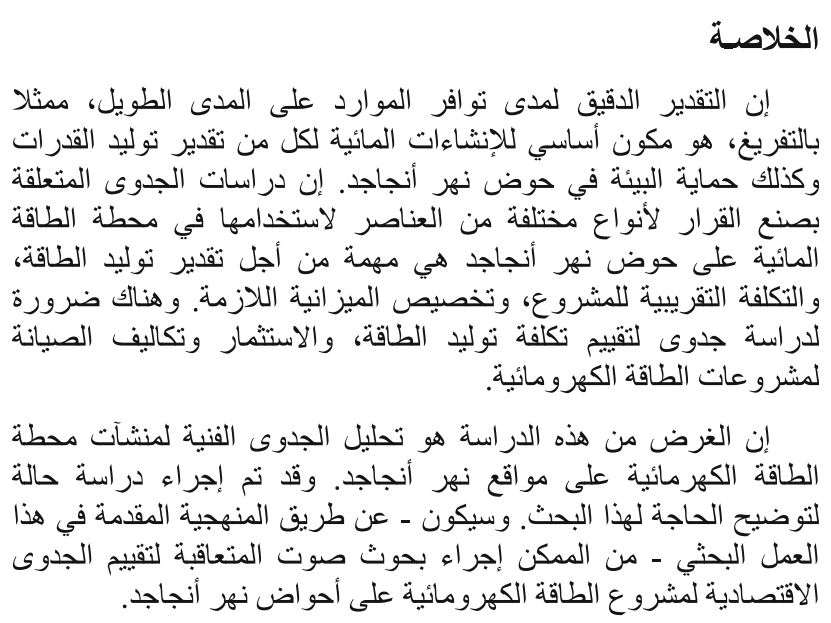

\section{Introduction}

Estimation of flow volumes from an ungauged river basin is essential for planning and design of water resources' projects such as the design of storage facilities, assessment of water availability for municipal, agricultural or industrial purposes, as well as for planning irrigation operations, estimating future development for water supplies for power generation and further necessities.

The socioeconomic development and increased living standards together with the fast growing industry have forced a major increase in electricity demand and generation. Being the basic input of all kinds of economic activities, electrical energy has become an indispensable life standard.

Small hydropower plants have emerged as an energy source which is renewable, easily developed, inexpensive and harmless to the environment [1]. 
Fig. 1 Ulucay river and project area
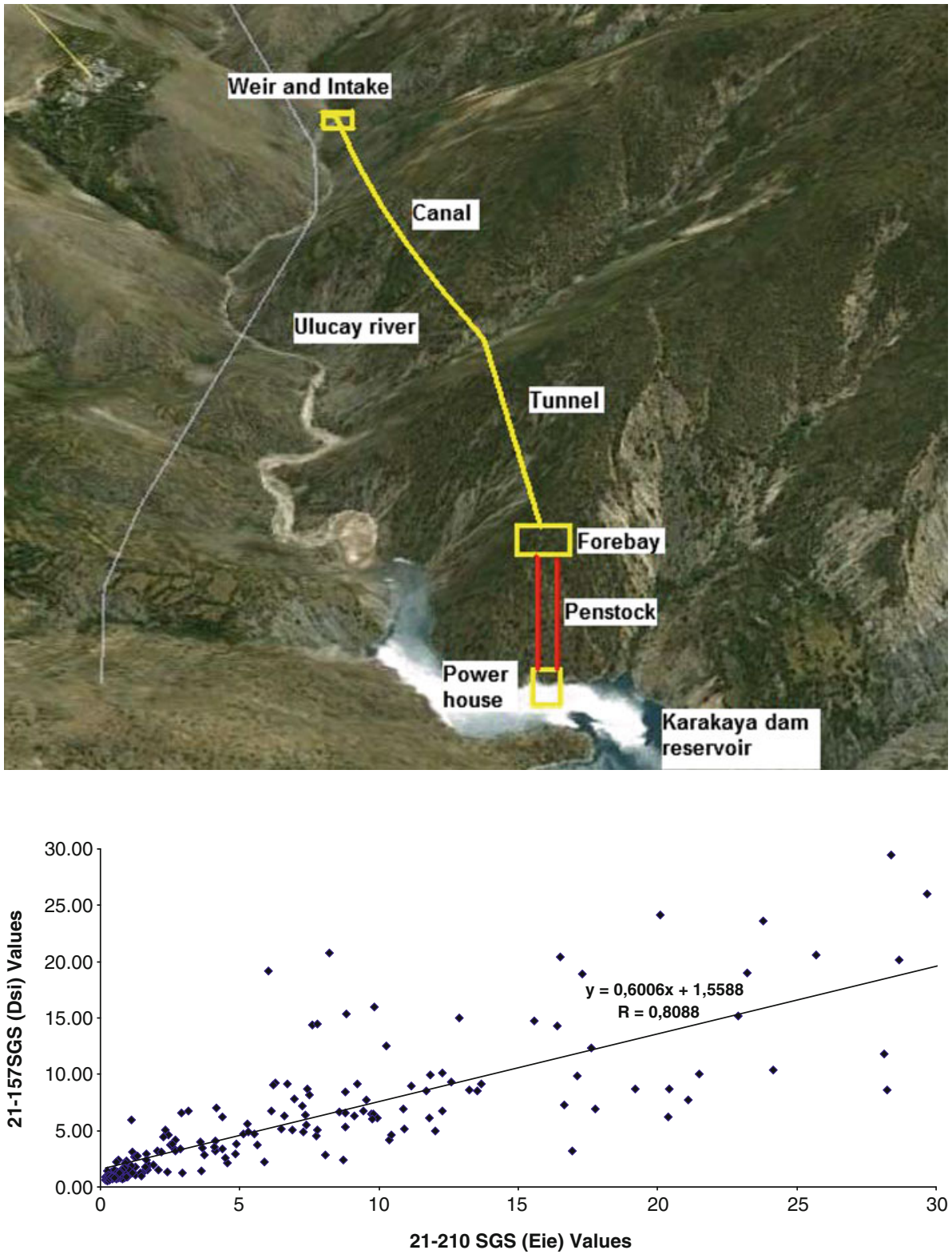

Hydropower is the most reliable, new source of power generation for the future; its share is more than $92 \%$ of the renewable energy generated [2].

In order to increase renewable energy production, enormous research is carried out for developing efficient, small hydropower plants. In this regards, European Small Hydro Association has issued a guideline for designing small hydro plants [3]. However, feasibility studies should not be neglected for the suitable evaluation and assessment of bigger hydro projects.

In the river basins with no flow-gaugings, the discharges in certain sections can be estimated taking into account the parameters like the basin area, rainfall, evaporation, weather temperature and altitude above sea level, besides the correla- tion-regression technique from a nearby gauged stream. The natural flow statistics may be estimated for an ungauged site, which may include the long term mean flow and flow duration curve, monthly mean flows and monthly flow duration curves.

Regionalization can be defined as the transfer of information from one catchment to another [4]. This information may consist of characteristics describing hydrological data or models. In order to reach a greater confidence in extrapolating hydrological behavior from catchments with flow records for an ungauged catchment, all the data should form a relatively homogeneous group ([5-7]). Vandewiele and Elias [8] reconstruct monthly runoffs for basins which are notably ungauged; Post and Jakeman [9] and 
Table 1 The Cardakli Weir average monthly flow data 1985-2004 (m³/s)

\begin{tabular}{|c|c|c|c|c|c|c|c|c|c|c|c|c|c|}
\hline Year & October & November & December & January & February & March & April & May & June & July & August & September & Average \\
\hline 1985 & 0.96 & 2.23 & 1.73 & 3.24 & 6.76 & 10.23 & 13.67 & 3.96 & 1.74 & 1.03 & 0.75 & 0.66 & 3.91 \\
\hline 1986 & 0.96 & 1.25 & 1.26 & 3.56 & 5.10 & 8.80 & 9.42 & 3.77 & 2.22 & 1.06 & 0.73 & 0.69 & 3.24 \\
\hline 1987 & 1.57 & 2.85 & 2.24 & 5.02 & 8.68 & 11.91 & 23.89 & 14.51 & 4.22 & 1.79 & 1.03 & 0.76 & 6.54 \\
\hline 1988 & 2.17 & 7.77 & 12.71 & 7.04 & 7.74 & 16.57 & 36.14 & 18.54 & 4.94 & 2.64 & 1.42 & 1.04 & 9.89 \\
\hline 1989 & 7.06 & 5.23 & 4.76 & 3.26 & 3.19 & 7.89 & 4.69 & 1.89 & 1.12 & 0.73 & 0.59 & 0.57 & 3.41 \\
\hline 1990 & 1.01 & 6.02 & 9.39 & 3.82 & 7.80 & 12.64 & 14.61 & 6.78 & 2.31 & 1.31 & 0.86 & 0.85 & 5.62 \\
\hline 1991 & 0.85 & 1.35 & 1.49 & 1.21 & 2.42 & 10.17 & 6.60 & 6.14 & 1.95 & 1.52 & 0.85 & 0.79 & 2.95 \\
\hline 1992 & 1.10 & 3.45 & 6.52 & 4.92 & 4.57 & 8.81 & 19.11 & 16.16 & 6.60 & 2.46 & 1.40 & 1.12 & 6.35 \\
\hline 1993 & 1.30 & 3.99 & 9.09 & 4.91 & 5.59 & 12.50 & 30.89 & 20.82 & 6.29 & 3.18 & 2.22 & 1.52 & 8.52 \\
\hline 1994 & 2.16 & 2.53 & 2.73 & 5.18 & 10.56 & 8.07 & 5.75 & 3.25 & 1.94 & 1.57 & 1.57 & 1.62 & 3.91 \\
\hline 1995 & 1.23 & 6.16 & 5.17 & 7.36 & 8.78 & 14.92 & 20.59 & 9.35 & 3.79 & 1.73 & 1.06 & 0.98 & 6.76 \\
\hline 1996 & 1.35 & 4.75 & 1.71 & 9.26 & 10.21 & 22.89 & 29.73 & 20.95 & 5.09 & 2.17 & 1.32 & 1.12 & 9.21 \\
\hline 1997 & 2.69 & 2.69 & 9.93 & 5.07 & 6.06 & 5.12 & 24.40 & 19.37 & 2.98 & 1.45 & 0.87 & 0.80 & 6.78 \\
\hline 1998 & 3.72 & 8.22 & 8.72 & 4.19 & 6.97 & 15.32 & 19.16 & 8.82 & 3.36 & 1.75 & 0.98 & 0.77 & 6.83 \\
\hline 1999 & 0.83 & 1.79 & 6.49 & 3.56 & 7.01 & 7.25 & 15.18 & 3.88 & 1.56 & 0.97 & 0.78 & 0.70 & 4.16 \\
\hline 2000 & 0.84 & 0.74 & 0.95 & 2.12 & 3.25 & 6.78 & 15.51 & 4.50 & 1.68 & 0.89 & 0.65 & 0.60 & 3.21 \\
\hline 2001 & 0.90 & 0.89 & 1.42 & 1.93 & 2.58 & 10.01 & 8.64 & 8.57 & 2.43 & 1.54 & 0.89 & 0.76 & 3.38 \\
\hline 2002 & 0.80 & 0.93 & 10.45 & 6.27 & 7.77 & 14.43 & 20.33 & 9.11 & 2.80 & 1.34 & 0.98 & 0.80 & 6.34 \\
\hline 2003 & 0.89 & 1.23 & 1.28 & 2.86 & 4.67 & 11.93 & 26.30 & 9.21 & 3.17 & 1.25 & 0.88 & 0.81 & 5.37 \\
\hline 2004 & 1.47 & 4.27 & 9.76 & 7.89 & 9.33 & 17.10 & 13.49 & 9.18 & 2.82 & 1.29 & 0.78 & 0.73 & 6.51 \\
\hline Average & 1.69 & 3.42 & 5.39 & 4.63 & 6.45 & 11.67 & 17.90 & 9.94 & 3.15 & 1.58 & 1.03 & 0.88 & 5.65 \\
\hline
\end{tabular}

Sefton and Howarth [10] predict daily flow time series by developing relationships between the parameters of a daily time step rainfall-runoff model and physical catchment descriptors.

This study aims at giving a general idea about the feasibility assessment of hydropower projects in ungauged river basins. In this respect, a feasibility report is of great importance for it is capable of performing desired computations and is developed by a highly experienced group of planners and engineers. Case study gains foreground in this research work which will be applied to the Cardakli Weir and hydropower plant in Turkey.

\section{Feasibility Study}

This feasibility study contains an estimation of design flow, design and probable maximum floods; determination of power potential for a range of dam or weir heights and installed capacities for project optimization; determination of the project design earthquake; design of all structures in sufficient detail; determination of the diversion structures' dimensions and project schedule; optimization of the project layout, water levels and components; production of a detailed cost estimate; and finally, an economic and financial evaluation of the project along with a feasibility report.

\subsection{Description of the Project Area}

The Cardakli Weir and hydropower plant will be constructed on the Ulucay River in the countryside of Sivrice at the Elazig region where continental climate is mostly influential. Ulucay basin $\left(207,0 \mathrm{~km}^{2}\right)$ having a main branch length of $25 \mathrm{~km}$, originates in the Hazarbaba Mountains, and receives flow from one major tributary before it discharges into the Karakaya Dam reservoir. Elevations range from 700 to 2,366 m. The Ulucay basin has warm, humid summers and cold winters. Heavy snowfalls are not rare in November, December, January, and February, while the driest months are July and August. The average annual precipitation is about $594.7 \mathrm{~mm}$. The temperatures are $-1.4{ }^{\circ} \mathrm{C}$ in January and $29.5^{\circ} \mathrm{C}$ in August $[11,12]$. Three-dimensional topographic map of the Ulucay River is shown in Fig. 1.

The geological structure of the site is obtained from the Earthquake Maps of Turkey prepared by The Ministry of Public Works and Settlement in 1996, which indicates that the region is sited in a 1 st degree earthquake region.

\subsection{Hydrology Data}

There is no flow observation station on the Ulucay River. For the estimation of water potential of the river in the study, the area Buyukcay (no. 21-210 (DSI) SGS), which is in the same 
basin, has been taken into account. The daily flow observation data of no. 21-210 SGS between 1985 and 2004 are present in official sources. The missing daily average flow values of no. 21-210 SGS from 2004 have been completed by those of no. 21-217 of Seyhan River SGS.

The catchment area of the Ulucay River has been identified as $207.0 \mathrm{~km}^{2}$ and the average annual precipitation is $594.7 \mathrm{~mm}$ according to the data collected by Karakaya and Hazar stations $[11,12]$.

The flows of the Ulucay River have been estimated by use of the daily flow values of no. 21-210 (DSI, rainfall area $=205.0 \mathrm{~km}^{2}$ ) SGS. During 2004 which is seen as ungauged in the flow observation yearbook, the flow observation values of no. 21-217 (DSI, rainfall area $=339.0 \mathrm{~km}^{2}$ ) Seyhan River SGS were used. The method of correlation and regression has been used for completing the missing data. Operations have been done in the same period of years during which both stations made measurements. Between these two stations, the meaningful correlation equation has been established as $y=0,6006 X+1.5588$, and the correlation coefficient as $R=0.8072$. By means of this correlation equation, the missing year 2004 has been completed. For the location of no. 21-210 SGS, the daily flow values in the observation period 1985-2004 have been calculated and transferred to the Ulucay river with the area ratio(207.0/205.0). The regression equation is illustrated in Fig. 2. The calculated monthly average flow $\left(\mathrm{m}^{3} / \mathrm{s}\right)$ values of the Ulucay river are given in Table 1 and the flow-duration curve is shown in Fig. 3.

\subsection{Design Flow and Power Optimization}

The design flow of a project is the most important feature of hydropower projects. All the other components of the projects are designed according to the selected design discharge.

Depending on this design discharge, the transmission canal dimensions, the penstock diameter and power central dimensions have been selected; based on these data, the net heads have been established with hydraulic calculations.

Normally, design discharges corresponding to $20-30 \%$ of time are appropriate as the design discharge. The discharge used in the Cardakli Feasibility Report, is $8 \mathrm{~m}^{3} / \mathrm{s}$ and it corresponds to $22 \%$ of time in flow duration curve.

Together with the net head corresponding to each of selected discharges, the installed power and annual production has been calculated. The investigations have been carried out based on the $6.00,6.25,6.50,6.75,7.00,7.25,7.50$, $7.75,8.00,8.25,8.50,8.75,9.00,9.25$ and $9.50 \mathrm{~m}^{3} / \mathrm{s}$ discharges. The total cost, annual income and annual expense rates pertaining to each discharge and installed power have been specified. Then, the profitability and marginal profitability calculations have been done, and the optional system whose marginal rent ability is closest to 1 , and which has a design discharge of $8.0 \mathrm{~m}^{3} / \mathrm{s}$ and $11.03 \mathrm{MW}$ installed power has been obtained as the optimal result. Generator efficiency is given as $97 \%$. Transformer losses, parasitic energy losses and annual downtime losses are assumed as 1, 2 and $3 \%$, respectively. Energy cost escalation rate is assumed as $0 \%$. The calculation details are given in Table 2.

\subsection{Components of the Project}

The components of the Cardakli HEPP project and the feasibility, presented in this study, are listed below:

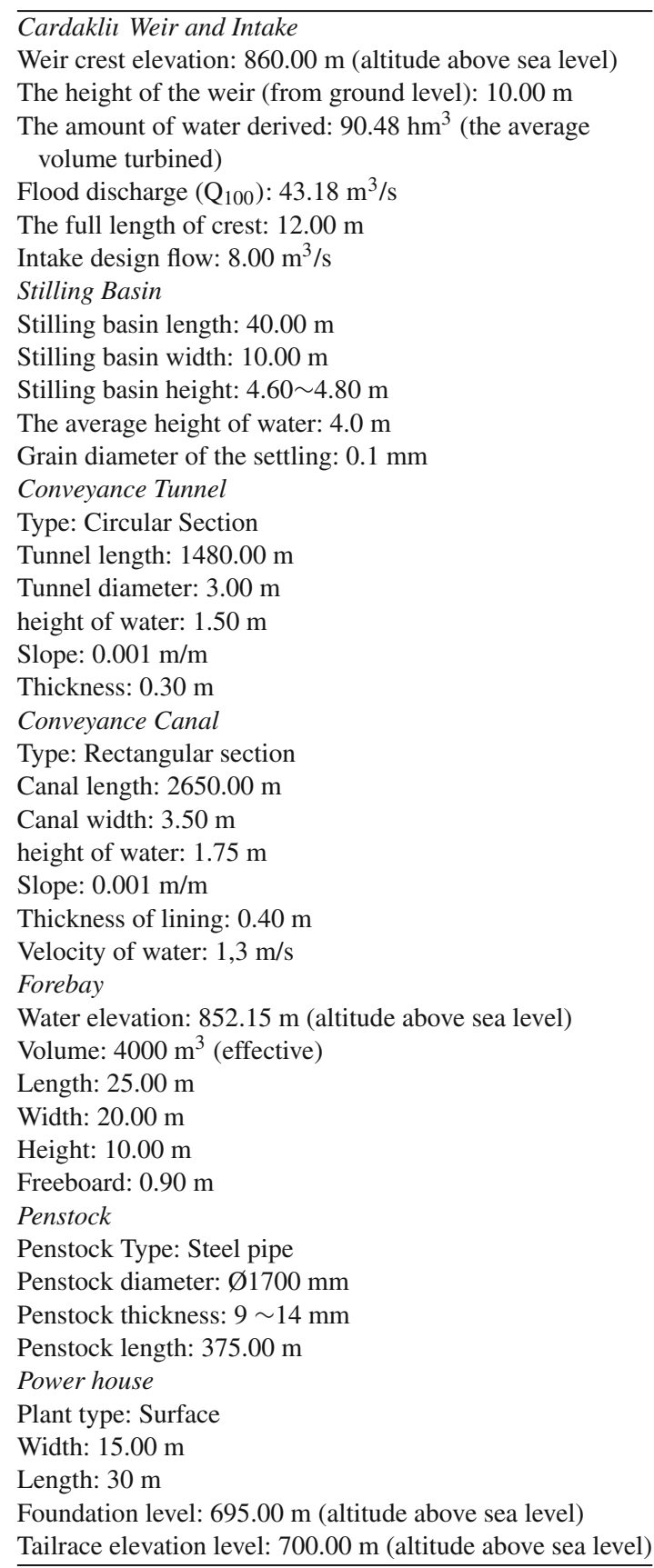

Weir crest elevation: $860.00 \mathrm{~m}$ (altitude above sea level)

The height of the weir (from ground level): $10.00 \mathrm{~m}$

The amount of water derived: $90.48 \mathrm{hm}^{3}$ (the average volume turbined)

Flood discharge $\left(\mathrm{Q}_{100}\right): 43.18 \mathrm{~m}^{3} / \mathrm{s}$

The full length of crest: $12.00 \mathrm{~m}$

design flow: $8.00 \mathrm{~m}^{3} / \mathrm{s}$

Stilling basin height: $4.60 \sim 4.80 \mathrm{~m}$

The average height of water: $4.0 \mathrm{~m}$

Grain diameter of the settling: $0.1 \mathrm{~mm}$

Tunnel diameter: $3.00 \mathrm{~m}$

height of water: $1.50 \mathrm{~m}$

Slope: $0.001 \mathrm{~m} / \mathrm{m}$

Type: Rectangular section

Canal length: $2650.00 \mathrm{~m}$

Slope: $0.001 \mathrm{~m} / \mathrm{m}$

Forebay

Volume: $4000 \mathrm{~m}^{3}$ (effective)

Length: $25.00 \mathrm{~m}$

Penstock

Penstock Type: Steel pipe

Penstock diameter: $\varnothing 1700 \mathrm{~mm}$

Penstock thickness: $9 \sim 14 \mathrm{~mm}$

Power house

Plant type: Surface

Width: $15.00 \mathrm{~m}$

Foundation level: $695.00 \mathrm{~m}$ (altitude above sea level)

m (altitude above sea level) 
continued

Turbine Characteristics

Type: Horizontal shaft Francis turbine

Installed power: $5.51 \mathrm{MW}$ (Total: 11.03 MW)

Unit Number: 2

Design flow: $4.00 \mathrm{~m}^{3} / \mathrm{s}$ (Total: $8.00 \mathrm{~m}^{3} / \mathrm{s}$ )

Gross head: $162.00 \mathrm{~m}$

Net head: $155.80 \mathrm{~m}$

Energy Transmission line

Conductor characteristics: 3 / 0 AWG

Length: $14 \mathrm{~km}$

Region: 2

Rated voltage: $34.5 \mathrm{kV}$

Roads

$10 \mathrm{~km}$ : of access road for the access to the components above

\subsection{Estimated Cost of the Project}

The unit prices of General Directorate of State Hydraulic Works and Ministry of Public Works and Housing for 2010 are used for cost estimations. The length of access roads, transmission canals and tunnels are estimated from the $1 / 25.000$ scaled map of the area, therefore scaling inaccuracies include the cost estimation. The reinforcing steel is supplied from Iskenderun and the cement from Elazig which are close to the location of the site. The exchange rate is derived from the statistics of Central Bank of the Republic of Turkey for the year 2010 as $1.52 \$ / T L$. The cost estimation of the Cardakli Hydropower Project is tabulated in Table 3.

\subsection{Energy Production}

The water of the Ulucay River is diverted by weir to a conveyance tunnel-canal, and then through a penstock to the turbines with total installed power of $11.02 \mathrm{MW}$ and annual energy generation of $40.51 \mathrm{GWh}$ in powerhouse that is located on $700.00 \mathrm{~m}$ elevation. Water is then discharged back into the Ulucay River which flows again into the Karakaya Dam reservoir.

The gross head of the project is $162.08 \mathrm{~m}$ and the discharge flow is determined as $8.0 \mathrm{~m}^{3} / \mathrm{s}$. The monthly energy produc- tion data of the Ulucay River are given in Table 4 and the energy graph is shown in Fig. 4.

\subsection{Firm and Secondary Energy}

Firm capacity is the amount of energy available for production or transmission which can be (and in many cases must be) guaranteed to be available at a given time. Firm energy refers to the actual energy guaranteed to be available. Firm energy is the energy that a plant can generate 95 percent of the time. Cardakli hydropower plant is generated firm energy, $7.82 \mathrm{GWh}$.

Secondary energy refers to all available energy above and beyond firm energy. Energy producers such as hydroelectric plants and wind farms may have secondary energy available due to unexpected weather or seasonal conditions. Secondary energy is not guaranteed. Cardakli hydropower plant is generated secondary energy, $32.69 \mathrm{GWh}$.

\subsection{Economic Analysis}

The economic analysis, envisaged economic life of the project for the Cardakli HEPP was predicted as 50 years. The key question related to the economics of the project is who will consume the electricity produced by the project. Energy-purpose projects, the avoided cost of energy is entered as firm energy 0.07 US $\$ / \mathrm{kWh}$ and secondary energy $0.06 \$ / \mathrm{kWh}$ which was the average value in the market for the year 2010 . There is peak power benefit to plant with no storage is considered to be worthless. As a result of the calculations, 7.82 GWh firm energy $32.69 \mathrm{GWh}$ secondary energy, total 40.51 GWh energy production per year is planned. As a result, the total energy benefit of the Cardakli HEPP is calculated as 2.511.620 \$. The project is examined in two parts which take into account the annual expenses, these, interest, depreciation and amortization expenses consist of operating and maintenance costs. Energy-purpose investments, interest and depreciation as a factor of $9.5 \%$ interest rate and 50 year economic life of the project correspond souts to the value of 0.09603. Operation and maintenance expenses, as well as
Fig. 3 Flow-duration curve of Cardakli HEPP




Table 2 Design flow and power optimization studies

\begin{tabular}{|c|c|c|}
\hline \multirow[t]{2}{*}{ Type of work } & \multicolumn{2}{|c|}{$\begin{array}{l}\text { Years of investment } \\
\text { 1. Year }\end{array}$} \\
\hline & First 6 months & The second 6 months \\
\hline \multicolumn{3}{|l|}{ Civil work } \\
\hline Business, building site facilities & 250.000 & \\
\hline Transportation routes & 100.000 & 112.500 \\
\hline Weir and settling Basin & & 81.806 \\
\hline Transmission tunnel & 567.158 & 623.874 \\
\hline Transmission canal & 261.328 & 287.461 \\
\hline Forebay & & 260.819 \\
\hline \multicolumn{3}{|l|}{ Penstocks } \\
\hline Power house & & 50.750 \\
\hline Unknown (\% 5) & 55.799 & 70.861 \\
\hline Civil work total & 1.234 .285 & 1.488 .071 \\
\hline \multicolumn{3}{|l|}{ Electromechanical equipment } \\
\hline Turbine, generator, switchgear field and installation works & 103.786 & 1.007 .573 \\
\hline \multicolumn{3}{|l|}{ Energy transmission line } \\
\hline Unknown (\% 5) & 25.189 & 50.379 \\
\hline Electromechanical equipment total & 528.976 & 1.057 .951 \\
\hline Total plant cost & 1.700 .761 & 2.546 .022 \\
\hline \multicolumn{3}{|l|}{ Other expensive } \\
\hline Study, project, consultancy costs & 75.000 & 75.000 \\
\hline Independent consulting expense & 12.500 & 12.500 \\
\hline Expropriation & & 50.000 \\
\hline Insurance expense & 10.000 & 10.000 \\
\hline Taxes & 170.076 & 254.602 \\
\hline Total project cost (USD) & 1.968 .337 & 2.948 .125 \\
\hline
\end{tabular}

criteria for each unit were taken into account by means of Dsi factors. Because of these principles, the total annual cost of the project is calculated as 1.306.759 \$. Income and expense ratio (Profitability) was calculated as 2.08 for the Cardakli HEPP with respect to this cost ratio.

\section{Conclusions}

The feasibility works has resulted in that a Cardakli hydropower project on the ungauged Ulucay river basin is technically favorable, potentially, commercially viable and could bring to the community financial and other benefits.

The typical design lifetime for hydropower project is approximately 50 years, but a large proportion of the equipment (weir, grid connection, cabling, other infrastructure) has a much longer lifetime. Although other parts like control equipment and electro mechanic equipment either have a shorter life time or need periodic refurbishing. Consequently the long term financial benefits of the hydro project seem to be very useful.

An increase in renewable energy generation is world priority over the long term future. With a target of $10 \%$ of gross electricity consumption in 2015 , the aim is set to increase this to $20 \%$ by 2020 . It is also possible that the renewable share in production may increase further after this date. Because the importance of renewable energy increases over time, the long term significance will be maintained.

This paper presents a method for estimating hydropower capacity of ungauged sites. The results obtained from this study suggest this, especially in the catchments with inadequate or non-flow gauging. Solutions that are faster and more affordable than the geodetic gauging can be obtained with the values obtained depending on the topographic, physical and hydrometeorological parameters of the catchments itself.

In the feasibility and master plan works, the project discharge could easily be identified by obtaining the "stream rainfall-flow parameters" with the method presented in this 
Table 2 continued

\begin{tabular}{|c|c|c|c|}
\hline \multirow[t]{2}{*}{ Type of work } & \multicolumn{2}{|c|}{$\begin{array}{l}\text { Years of investment } \\
\text { 2. Year }\end{array}$} & \multirow[t]{2}{*}{ Total $(\$)$} \\
\hline & First 6 months & The second 6 months & \\
\hline \multicolumn{4}{|l|}{ Civil work } \\
\hline Business, building site facilities & & & 250.000 \\
\hline Transmission canal Transportation routes & & & 212.500 \\
\hline Weir and settling basin & 245.419 & 490.839 & 818.065 \\
\hline Transmission tunnel & 850.737 & 794.021 & 2.835 .790 \\
\hline Transmission canal & 391.992 & 365.859 & 1.306 .640 \\
\hline Forebay & 365.147 & 417.310 & 1.043 .276 \\
\hline Penstocks & & 949.248 & 949.248 \\
\hline Power house & 812.007 & 152.251 & 1.015 .009 \\
\hline Unknown (\% 5) & 133.265 & 158.476 & 418.401 \\
\hline Civil work total & 2.798 .567 & 3.328 .006 & 8.848 .929 \\
\hline \multicolumn{4}{|l|}{ Electromechanical equipment } \\
\hline $\begin{array}{l}\text { Turbine, generator, switchgear field and installation } \\
\text { works }\end{array}$ & 1.211 .359 & 2.015 .146 & 4.337 .864 \\
\hline Energy transmission line & & 400.000 & 400.000 \\
\hline Unknown (\% 5) & 75.568 & 125.757 & 276.893 \\
\hline Electromechanical equipment total & 1.586 .927 & 2.640 .903 & 5.814 .757 \\
\hline Total plant cost & 4.385 .494 & 5.968 .909 & 14.601.186 \\
\hline \multicolumn{4}{|l|}{ Other expensive } \\
\hline $\begin{array}{l}\text { Study, project, consultancy costs } \\
\text { Expropriation }\end{array}$ & 75.000 & 75.000 & $\begin{array}{l}300.000 \\
50.000\end{array}$ \\
\hline Insurance expense & 10.000 & 10.000 & 40.000 \\
\hline Taxes & 438.549 & 596.891 & 1.460 .119 \\
\hline Total project cost (USD) & 4.921 .544 & 6.663 .300 & 16.501.305 \\
\hline
\end{tabular}

Table 3 Cost estimation of Cardakli HEPP

\begin{tabular}{lllll}
\hline$[1] \mathrm{Q}\left(\mathrm{m}^{3} / \mathrm{s}\right)$ & {$[2]$ Hnet $(\mathrm{m})$} & {$[3]$ installed power $(\mathrm{MW})$} & $\begin{array}{l}{[4] \text { Produced energy- }} \\
\text { seconder }(\mathrm{GWh} / \text { year })\end{array}$ & $\begin{array}{l}\text { [5] Produced energy-firm } \\
(\mathrm{GWh} / \text { year })\end{array}$ \\
\hline 6.00 & 155.67 & 8.26 & 32.27 & 6.67 \\
6.25 & 155.73 & 8.61 & 32.35 & 6.79 \\
6.50 & 155.76 & 8.96 & 32.40 & 7.01 \\
6.75 & 155.78 & 9.30 & 32.43 & 7.16 \\
7.00 & 155.80 & 9.65 & 32.47 & 7.33 \\
7.25 & 155.82 & 9.99 & 32.51 & 7.50 \\
7.50 & 155.83 & 10.34 & 32.55 & 7.67 \\
7.75 & 155.84 & 10.68 & 32.59 & 7.72 \\
8.00 & 155.86 & 11.03 & 32.69 & 7.75 \\
8.25 & 155.88 & 11.38 & 32.72 & 7.82 \\
8.50 & 155.90 & 11.72 & 32.73 & 8.09 \\
8.75 & 155.91 & 12.07 & 32.75 & 8.22 \\
9.00 & 155.94 & 12.42 & 32.77 & 8.36 \\
9.25 & 155.95 & 12.76 & 32.79 & 8.49 \\
9.50 & 155.99 & 13.11 & 32.80 & 8.63 \\
\hline
\end{tabular}


Table 3 continued

\begin{tabular}{llllll}
\hline $\begin{array}{l}\text { [6] The annual energy } \\
\text { produced (GWh/year) }\end{array}$ & $\begin{array}{l}\text { [7] Annual income } \\
(\$)\end{array}$ & $\begin{array}{l}\text { [8] Total cost } \\
(\$)\end{array}$ & $\begin{array}{l}\text { [9] Annual expense } \\
(\$)\end{array}$ & $\begin{array}{l}\text { [10] Annual net income [11] Profitability } \\
(\$)\end{array}$ \\
\hline 38.94 & 2.414 .280 & 15.903 .198 & 1.168 .200 & 1.078 .523 & 1.80 \\
39.14 & 2.426 .680 & 15.998 .675 & 1.174 .200 & 1.107 .285 & 1.83 \\
39.41 & 2.443 .420 & 16.103 .234 & 1.182 .300 & 1.140 .387 & 1.87 \\
39.59 & 2.454 .580 & 16.201 .738 & 1.187 .700 & 1.168 .116 & 1.90 \\
39.81 & 2.468 .220 & 16.179 .890 & 1.194 .300 & 1.197 .704 & 1.97 \\
40.02 & 2.481 .240 & 16.278 .898 & 1.200 .600 & 1.227 .086 & 2.01 \\
40.23 & 2.494 .260 & 16.363 .004 & 1.206 .900 & 1.256 .468 & 2.04 \\
40.31 & 2.499 .220 & 16.435 .022 & 1.209 .300 & 1.278 .204 & 2.08 \\
40.51 & 2.511 .620 & 16.501 .305 & 1.215 .300 & 1.306 .759 & 1.224 .981 \\
40.54 & 2.513 .480 & 16.508 .909 & 1.216 .200 & 1.198 .538 & 1.95 \\
40.82 & 2.530 .840 & 16.617 .595 & 1.224 .600 & 1.184 .527 & 1.87 \\
40.97 & 2.540 .140 & 16.685 .070 & 1.229 .100 & 1.180 .515 & 1.86 \\
41.13 & 2.550 .060 & 16.752 .544 & 1.233 .900 & 1.161 .873 \\
41.28 & 2.559 .360 & 16.820 .018 & 1.238 .400 & 1.242 .900 & 1.82 \\
41.43 & 2.568 .660 & 16.887 .493 & 1.804 & \\
\hline
\end{tabular}

$[3]=[1] *[2] * 8.85 / 1000,[4]=[6]-[5],[5]=$ Produced energy from firm discharge $[6]=[3] *$ (Annual working time) $[7]=[6] * 0.062 \$$ $(0.06 \$ / \mathrm{kWh}$ Average value in the market in Turkey) [8] = Total $\operatorname{cost}($ Civil work+ electromechanical equipment $)[9]=[6] * 0.03 \$$ $(0.03 \$ / \mathrm{kWh}$ mechanical failure and operating expenses), [10] = [7]-[9], [11] = [7]/[9]

Table 4 Cost estimation of Cardakli HEPP

\begin{tabular}{|c|c|c|c|c|c|c|c|c|c|c|c|c|c|}
\hline Year & October & November & December & January & February & March & April & May & June & July & August & September & Total \\
\hline 1985 & 0.47 & 1.65 & 1.26 & 2.81 & 5.03 & 6.58 & 7.81 & 3.55 & 1.23 & 0.54 & 0.26 & 0.16 & 31.35 \\
\hline 1986 & 0.48 & 0.69 & 0.78 & 2.67 & 3.73 & 7.74 & 6.69 & 3.35 & 1.67 & 0.57 & 0.24 & 0.18 & 28.79 \\
\hline 1987 & 1.04 & 2.16 & 1.79 & 4.62 & 6.35 & 8.00 & 7.94 & 8.07 & 3.69 & 1.33 & 0.54 & 0.26 & 45.79 \\
\hline 1988 & 1.52 & 4.20 & 6.07 & 6.50 & 5.71 & 8.19 & 7.94 & 8.21 & 4.40 & 2.20 & 0.95 & 0.54 & 56.43 \\
\hline 1989 & 3.93 & 4.19 & 4.26 & 2.84 & 2.49 & 5.93 & 4.16 & 1.42 & 0.62 & 0.24 & 0.09 & 0.07 & 30.25 \\
\hline 1990 & 0.52 & 3.74 & 5.86 & 3.41 & 4.82 & 8.21 & 7.94 & 5.74 & 1.80 & 0.83 & 0.37 & 0.35 & 43.61 \\
\hline 1991 & 0.36 & 0.84 & 1.02 & 0.73 & 1.74 & 6.02 & 5.78 & 4.43 & 1.44 & 1.05 & 0.36 & 0.29 & 24.05 \\
\hline 1992 & 0.62 & 2.83 & 6.01 & 4.54 & 3.91 & 6.41 & 7.94 & 8.21 & 5.97 & 2.01 & 0.92 & 0.61 & 49.97 \\
\hline 1993 & 0.82 & 2.90 & 6.18 & 4.52 & 4.13 & 7.75 & 7.94 & 8.21 & 5.67 & 2.75 & 1.77 & 1.01 & 53.63 \\
\hline 1994 & 1.70 & 2.01 & 2.28 & 4.44 & 6.32 & 7.06 & 4.89 & 2.82 & 1.43 & 1.10 & 1.10 & 1.11 & 36.27 \\
\hline 1995 & 0.75 & 3.68 & 4.78 & 6.97 & 6.94 & 8.21 & 7.94 & 7.31 & 3.27 & 1.26 & 0.58 & 0.48 & 52.15 \\
\hline 1996 & 0.87 & 3.68 & 1.24 & 5.37 & 6.42 & 8.21 & 7.94 & 8.21 & 4.56 & 1.72 & 0.84 & 0.61 & 49.67 \\
\hline 1997 & 2.24 & 2.17 & 5.58 & 4.25 & 3.88 & 4.74 & 7.89 & 6.89 & 2.46 & 0.97 & 0.38 & 0.30 & 41.75 \\
\hline 1998 & 2.03 & 4.89 & 6.56 & 3.79 & 5.17 & 7.66 & 7.94 & 7.38 & 2.84 & 1.29 & 0.50 & 0.27 & 50.32 \\
\hline 1999 & 0.34 & 1.28 & 4.06 & 2.96 & 5.03 & 6.40 & 7.85 & 3.47 & 1.05 & 0.48 & 0.28 & 0.20 & 33.40 \\
\hline 2000 & 0.35 & 0.24 & 0.46 & 1.58 & 2.64 & 5.64 & 7.91 & 4.10 & 1.17 & 0.40 & 0.16 & 0.10 & 24.76 \\
\hline 2001 & 0.41 & 0.39 & 0.94 & 1.47 & 1.93 & 7.59 & 5.94 & 6.35 & 1.92 & 1.07 & 0.40 & 0.25 & 28.65 \\
\hline 2002 & 0.32 & 0.43 & 6.28 & 5.39 & 5.93 & 8.21 & 7.94 & 7.14 & 2.29 & 0.86 & 0.50 & 0.30 & 45.58 \\
\hline 2003 & 0.40 & 0.72 & 0.80 & 2.25 & 3.75 & 7.37 & 7.94 & 6.81 & 2.61 & 0.76 & 0.39 & 0.31 & 34.12 \\
\hline 2004 & 0.99 & 3.10 & 5.48 & 6.66 & 6.81 & 8.21 & 7.94 & 6.80 & 2.30 & 0.81 & 0.29 & 0.23 & 49.63 \\
\hline Average & 1.01 & 2.29 & 3.58 & 3.89 & 4.64 & 7.21 & 7.31 & 5.92 & 2.62 & 1.11 & 0.55 & 0.38 & 40.51 \\
\hline
\end{tabular}


Fig. 4 Energy production values (Gwh)

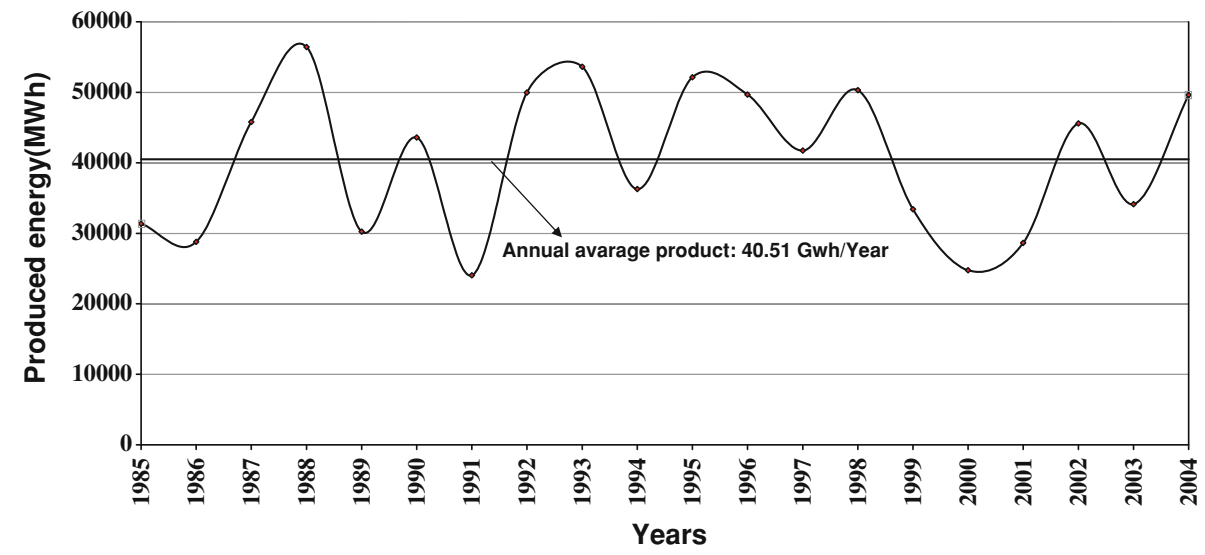

study (in the catchments with inadequate or non-flow gauging assessments), and accordingly the water construction to be built could be planned in a sound state and fast way.

Open Access This article is distributed under the terms of the Creative Commons Attribution License which permits any use, distribution, and reproduction in any medium, provided the original author(s) and the source are credited.

\section{References}

1. Adıgüzel, F.; Tutuş, A.: Small hydroelectric power plants in turkey. In: Proceedings of Hydro 2002, Development, Management, Performance. 4-7 November, pp. 283-293 (2002)

2. Yemtsa, G.; Steven, M.: Hydropower: The Small Versus Large Debate and the Policy Decisions Implications in Developing Countries. Leeds, United Kingdom (2009)

3. ESHA,: Guide on How to Develop a Small Hydropower Plant, European Small Hydropower Association-ESHA, Belgium (2004)

4. Bloschl, G.; Sivapalan, M.: Scale issues in hydrological modeling a review. Hydrological Processes 9, 251-290 (1995)

5. Nathan, R.J.; McMahon, T.A.: Identification of homogenous regions for the purposes of regionalisation. Journal of Hydrology 121, 217-238 (1990)
6. Pilgrim, D.H.: Some problems in transferring hydrological relationships between small and large drainage basins and between regions. Journal of Hydrology $\mathbf{6 5}, 49-72$ (1983)

7. Post, D.A.; Jakeman, A.J.: Relationships between catchment attributes and hydrological response characteristics in small Australian mountain ash catchments. Hydrological Processes 10, 877-892 (1996)

8. Vandewiele, G.L.; Elias, A.: Monthly water balance of ungauged catchments obtained by geographical regionalisation. Journal of Hydrology 170, 277-291 (1995)

9. Post, D.A.; Jakeman, A.J.: Predicting the daily streamflow of ungauged catchments in SE Australia by regionalising the parameters of a lumped conceptual rainfall-runoff model. Ecological Modelling 123, 91-104 (1999)

10. Sefton, CEM.; Howarth, SM.: Relationships between dynamic response characteristics and physical descriptors of catchments in England and Wales. Journal of Hydrology 211, 1-16 (1998)

11. DSI Current yearbooks, General Directorate of state hydraulic works, Ankara Turkey (2010)

12. EIE Results for the Years of Water Flow, General Directorate of electrical power resources survey and development Administration, Ankara, Turkey (2010) 